\title{
Causal Effect of Financial Market Frictions and Flight to Quality on Cost of Credit in Kenya
}

\author{
Barnabas Ochieng' Onyango $^{1^{*}} \quad$ Dr. Alphonce Juma Odondo ${ }^{1} \quad$ Prof. John Ernest Odada ${ }^{2}$ \\ 1.Faculty of Business and Economics, Tom Mboya University College (A constituent College of Maseno \\ University, Kenya) \\ 2.School of Business and Human Resource Development, Rongo University
}

\begin{abstract}
Financial market conditions have been declining over the past ten years globally as most developing countries continue to adopt more liberal financial policies, such conditions may amplify adverse shocks to the economy. The Kenyan Banking sector was highly profitable before the implementation of financial market frictions, with industry return on equity's average of $20 \%$. The ratio of credit supply to gross domestic product was $35 \%$; and the economy grew by $5.6 \%$. Nonetheless, after its adoption, listed Banks recorded negative Earnings per Share growth of $8.2 \%$, compared to an average positive growth of $14.1 \%$, The Net Interest Margin declined to $8.4 \%$ from $9.4 \%$. Studies relating to financial market frictions, flight to quality and Cost of Credit have produced mixed results. It was on this basis that this study sought to establish the effect of financial market frictions and flight to quality on cost of credit in Kenya. The study adopted correlational research design. Secondary data from the Kenyan Market for the period January 2009 to December 2019 was analyzed. Augmented Dickey Fuller and Philips-perron unitroot test was used to test the stationarity of the data. VECM was estimated to establish the speed of adjustment towards the long run equilibrium; Wald statistics was also estimated to establish short run causalities amongst the variables. Based on cointegrating equations, the error correction term indicated a negative sign and was significant at $5 \%$ level $(\mathrm{C}(1)=-0.153042, .0429<0.05)$, an indication that a long run relationship exists amongst the variables. Wald statistics revealed that the estimated coefficients in the VECM were insignificantly different from zero $(.8417 ; .5603 ; .9188>\mathrm{p}=0.05)$,however, Central Bank rate was found to be different from zero and significant at $5 \%$ level $(.0163>\mathrm{p}=0.05)$, an indication that there was a short run casualty running from the Central Bank rate to cost of credit. The study therefore recommends that for Micro finance institutions to maximize their profits they should adopt new technologies like Mobile Banking for their credit facilities, this does not require administrative and operation costs, in a bid to cope with the market shocks and frictions.
\end{abstract}

Keywords: Financial Market Frictions, Flight to Quality, Cost of Credit, Kenya

DOI: $10.7176 / \mathrm{JESD} / 12-6-07$

Publication date:March $31^{\text {st }} 2021$

\subsection{Introduction}

Globally, financial market frictions have been a major concern to many players in the financial sector. In the context of the capital asset pricing model, financial market frictions is defined as anything that interferes with trade. These frictions can cause a market participant to be exposed to more or less risk than he/she might prefer and can deviate from holding the market portfolio (Kiyotaki \& Wright, 1989; Mahony \& Qian, 2009; Trejos \& Wright, 1995). Financial market frictions generate real costs for MFIs, recognizing these costs helps in their allocation and whether they are worth absorbing, especially transactions costs, such costs depend in part on market structure which of course also depends on both the risk of the traded asset and trading volume. In small markets for risky assets, i.e, MFIs, participants look for counterparties because the fixed costs of credit supply are too large to be offset by the lower marginal costs of each transaction if transactions are few (Mahony \& Qian, 2009) . Market frictions are manifested as market power indivisibilities leading to economies of scale, economies of scope, imperfect information and incomplete market asymmetric information and positive transaction costs (Mahony \& Qian, 2009; Kumar \& Williamson, 1993).

Empirical implications of frictions in trading processes have been analyzed, especially in preference to credit supply and capital asset pricing. The result is that in times of economic distress and severe disruptions to credit markets, it is often observed that investors rebalance their portfolios towards less risky securities, especially in fixed-income markets. Kashyap, Stein, and Wilcox, (1993) noted that following tightening of monetary policy, there were systematic increases in the relative quantity of commercial paper compared to bank lending. This argument introduces the concept of flight-to-quality. Bernanke and Blinder, (1988)), explained that during economic turmoil, low-grade firms suffer more decreases in their production and spending than large corporations. On the other hand, Guler and Ozlale, (2005) found out that an increase in uncertainty, which could also be viewed as a rise in economy-wide risk, might generate a flight-to-quality effect. When investors fly to quality they move out of assets with higher expected risk, such as equities and increase demand for less risky assets such as bonds, they concluded that flight quality effect where negative equity return associated with large positive bond return. Thus, additional research in this field remains highly desirable and the creation of a general framework for flight- 
to-quality analyses is needed. An analogy that this study seeks to bridge.

To start up a business enterprise, individuals need starting capital. The act of lending money to individuals with the aim of starting a small business is termed as micro lending (Onyango \& Odondo, 2018). The major factor influencing MFIs not to advance as much credit to this less fortunate cadre in lending is the non-recoverability of costs, ( Mohane, Coetzee \& Grant, (2002); CBK, 2016; Onyango and Odondo, 2018). For MFIs To avail all their services and remain sustained and active in the market, financial institutions must cover costs and expenses incurred which may include; cost of operations, cost of borrowing, inflation costs, cost of default and other costs of delinquencies,(Khandare \& Alshebami, 2015; Miller, 2013; Maimbo \& Gallegos, 2014). Due to financial market frictions, market forces of demand and supply may be greatly interfered with, and as a consequence, finding the equilibrium quantity and price might be very illusive. According to (Mohane et al, (2002);Khandare \&Alshebami, (2015); Onyango and Odondo, (2018), When there is interest rate ceiling, and the equilibrium price is above the ceiling, the allocation of resources may be distorted, Individuals who may need loans, but due to their financial status lacks sufficient collaterals and in most cases, if they are uncreditworthy and do not qualify at the ceiling interest rate, are denied access or granted are granted at a more stringent terms and premium, this is the only sure way MFIs are able to recover their costs promptly.

Provisions in anticipation of loan losses entails assessing technical accounting standards, tax implications, internal processes, and statutory reporting and technology software harmonization (DeFond, Hu, Hung, \& $\mathrm{Li}$, 2011; Chen, Wang, \& Yao, 2013 ). Bernanke and Lown (1991); Gambacorta and Shin (2016); Kishan and Opiela (2000, 2006); Cohen and Scatigna (2016) established that bank capitalization has a significant impact on lending behaviour, suggesting that, to the extent that the provisions were taken out of capital, this would have dampened subsequent lending. Credit reference bureaus on the other hand, reduce borrowing cost and loan delinquencies to a moderate extent; it enhances effective risk identification/monitoring and microcredit extension, (Gaitho, 2013). Credit information sharing undoubtedly plays a pivotal role in reducing the information asymmetry that exists between banks and borrowers. From foregoing literature, most of the related studies largely focused on developed countries whose GDP were higher than those of developing countries. Therefore, results from such economies should be treated with a lot of caution in relation to developing economies like Kenya. Consequently, a country specific study is inevitable for clear policy formulation. It is on this basis that the study sought to establish the relationship between financial market frictions, flight to quality and cost of credit. The guiding hypotheses were;

$H_{01}$ Central Bank rate does not affect cost of credit in Kenya.

$H_{02}$ Provisions in anticipation of loan losses do not affect cost of credit in Kenya.

$H_{03}$ Non-performing loans does not affect cost of credit in Kenya.

$H_{04}$ Flight to quality and cost of credit in Kenya does not have a long run relationship

\subsection{Research Methodology \\ 2.1 Research Design}

Research design is the overall plan for obtaining answers to the research questions being studied and for handling some of the difficulties encountered during the research process. Saunders, Lewis, Thornhill, (2009) define a research design as a blueprint for conducting a study with maximum control over factors that may interfere with the validity of the findings. Kothari (2004) describe a research design as the arrangement of conditions for collection and analysis of data in a manner that aims to combine relevance to the research purpose with economy in procedure. This study will adopt correlation research design. Kothari (2004), states that correlation analysis studies the joint variation of two or more variables for determining the amount of correlation between two or more variables. In general, a correlational study is a quantitative method of research in which the similarities between two or more quantitative variables from the same group of subjects are determined.

\subsubsection{Correlation analysis.}

Correlational research design is suitable for studies that seek to establish relationships. This study adopted correlational research design. The study employed secondary data from the Kenyan Market for the period January 2009 to December 2019. The dependent variable was Cost of Credit while the independent variables were Central Bank Rate, provisions in anticipation of loan losses, Nonperforming loans and flight to quality - especially purchase of Government securities, like in this case Treasury bills.

\subsection{Study Area}

The study was conducted in Kenya, an African country in the Eastern region of the continent. The Country is surrounded by five other African countries namely; Ethiopia, Somalia, Uganda, Tanzania, and South Sudan. 
Kenya lies between latitudes $41 / 2^{\circ} \mathrm{N}$ and $41 / 2^{\circ} \mathrm{S}$ longitudes $34^{\circ} \mathrm{E}$ and $42^{\circ} \mathrm{E}$. The country covers 569,140 square kilometers of land and 11,227 square kilometers of water, with a total area of 580,367 square kilometers. Her population is approximately $47,564,296$ according to the 2019 population census. The GPS coordinates of Kenya show that the country is bisected by the equator. Approximately half of Kenya is in the northern hemisphere.

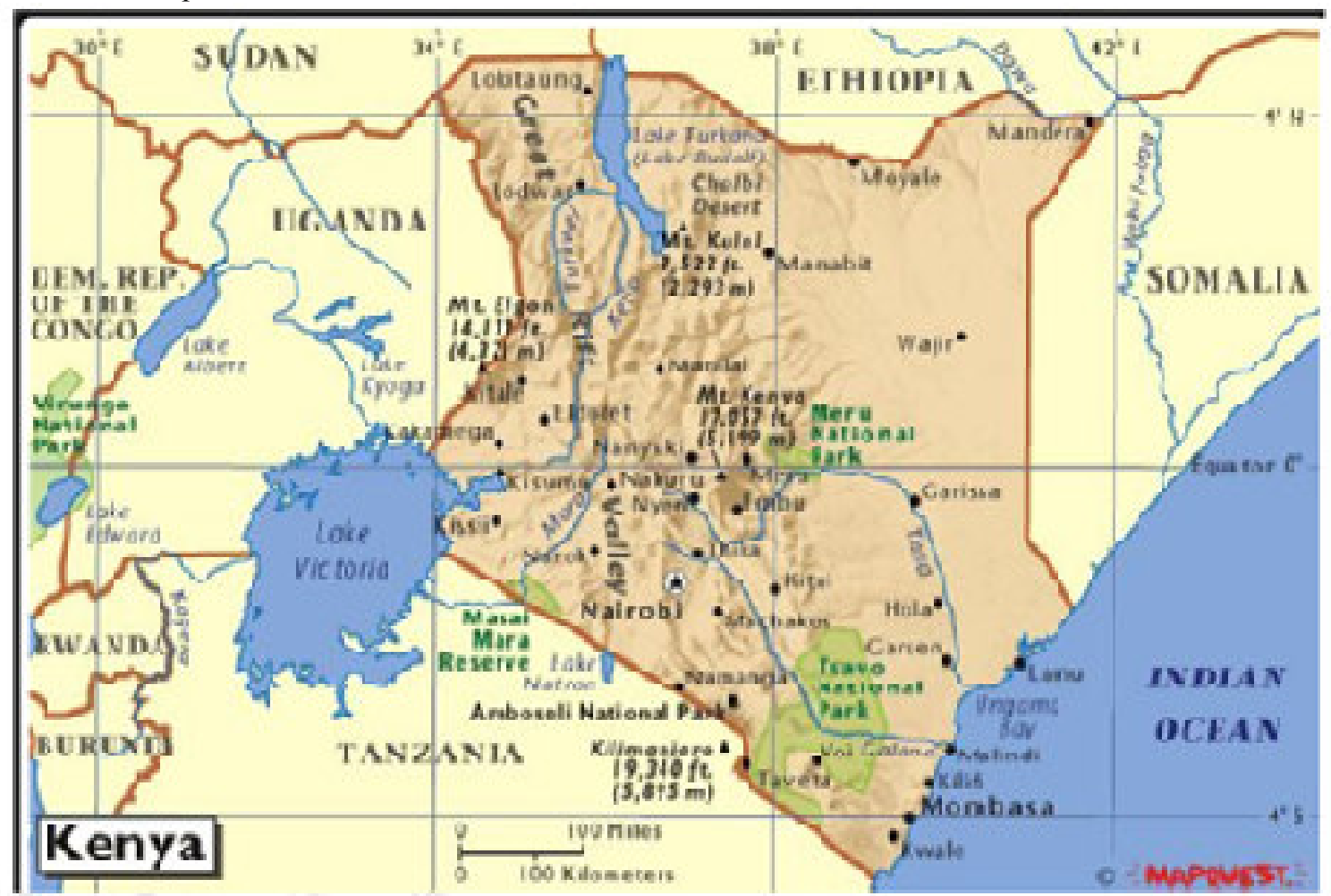

Figure 1.0: Position and shape of Kenya

\subsection{Data Type, Sources and Collection Methods}

The data used in this study was sourced mainly from financial statements of Banks, Bank Supervision reports, Official websites of commercial Banks, Think Business Banking Survey and publicly listed enterprises. Our time series data set covers the period from the first month of 2009 to the last month of 2019. We also used several macroeconomic series, which are mostly sourced from the Central Bank of Kenya website. This diminishes the problems associated with heterogeneous demand shocks, because the share of different types of loans in the banks' portfolios does not differ significantly.

\subsection{Model Specification.}

A general Vector Autoregressive Model (VAR) of order "P" below was used to generate VECM;

$$
Y_{t}=v+\mathrm{A}_{1} Y_{t-1}+\mathrm{A}_{2} Y_{t-2}+\ldots+\mathrm{A}_{p} Y_{t-p}+\varepsilon_{t}
$$

Where: $\mathrm{P}$ is a positive integer, $\mathrm{A}_{i}$ are fixed $(\mathrm{K} \times \mathrm{K})$ coefficient matrices for $i=1, v=$ is a fixed $(\mathrm{K} \times 1)$ vector of intercept terms, $\varepsilon_{t}$ is assumed to be multivariate normal, is a white noise with zero and positive definite covariance matrix $\varepsilon_{t} \sim \operatorname{iidN}\left(0, \sigma^{2} \varepsilon\right)$.

VECM was applied to find long-run equilibrium associations. To assess the short-run and long-run coefficients of the variables, we developed the following from equation (1.0) to form a VECM model and is generated recursively as; 


$$
\Delta C C_{t}=\phi+\sum_{i=1}^{k-1} \phi_{i} \Delta C C_{t-i}+\sum_{j=1}^{k-1} \phi_{j} \Delta C B R_{t-j}+\sum_{m=1}^{k-1} \phi_{m} \Delta P A L L_{t-m}+
$$

$$
\sum_{p=1}^{k-1} \phi_{p} \Delta N P L_{t-p}+\sum_{n=1}^{K-1} \phi_{n} \Delta T B L L_{t-n}+\lambda_{i} E C T_{t-1}+\mu_{i t}
$$

Where: $k-1=$ Shows the lag length, which is reduced by 1 .

$\lambda_{i}=$ This is the Speed of adjustment parameter with a negative sign. It measures the speed at which the dependent variable(s) returns to equilibrium after changes in independent variables. $\mu_{i t}=$ Residuals (Stochastic error term).

$\phi_{i}, \phi_{j}, \phi_{m}, \phi_{p}$ and $\phi_{n}=$ are short run dynamic coefficients of the model's adjustment long run equilibrium.

$\mathrm{CC}=$ Cost of Credit

$\mathrm{CBR}=$ Central Bank Rate

PALL $=$ Provisions in Anticipation of Loan Losses

$\mathrm{NPL}=$ Non Performing Loans

TBLL $=$ Treasury Bills

$E C T=($ Error Correction Term $)$, it is the lagged value of the residuals obtained from the cointegrating regression of the dependent variable on the regressors.

It contains long-run information derived from the long-run cointegrating relationships. This study expresses the lagged OLS residual obtained from the long-run cointegrating equations as;

$$
Y_{t}=\sigma+\eta_{j} X_{t}+\xi_{m} R_{t}+\mu_{t}
$$

From equation (1.2) we can re-write Error Correction Term (ECT) as;

$$
E C T_{t-1}=\left[Y_{t-1}-X_{t-1} \eta_{1}-R_{t-1} \xi_{1}\right]
$$

\subsection{Data Analysis.}

Augmented Dickey Fuller (ADF) unit-root test and Philips perron test (PP) was done to check the stationarity of the time series data on the basis of a null hypothesis that the time series were non stationary (i.e. $\delta=0$ ) and alternative hypothesis that the time series were stationary (i.e. $\delta \neq 0$ ). This was undertaken as a precautionary measure against estimation of spurious regression models (Sim et al., 1990).

The ADF unit root test will take the form of;

$$
\Delta Y_{t}=\mathrm{a}_{0}+\alpha Y_{t-1}+b_{2} \Delta Y_{t-1}+b_{3} \Delta Y_{t-2}+\ldots+\varepsilon_{t}
$$

where; $\Delta$ is the difference operator, $\mathrm{a}_{0}$ is a constant, and $\alpha$ is the autoregressive lag coefficient. The ADF then tests the hypothesis; the null hypothesis for the test is given below;

$H_{0}: \alpha=0$, there exists a unit root problem. If $\mathrm{t}$-statistic $>\mathrm{ADF}$ critical value, accept the null hypothesis. If $\mathrm{t}-$ statistic $<$ ADF critical value, reject the null hypothesis. If the null hypothesis is rejected, the data of the series is stationary and can be used for modeling without taking any difference of the series. The Dickey-Fuller test statistics have been criticized for their low power, especially in distinguishing between unit roots and near unit roots and in small sample data while Phillips-Perron (PP, 1988) test is more robust to serial correlation, time dependent heteroscedasticity and regime changes (Moosa \& Bhatti, 1997).

\subsection{Cointegration Test}

Cointegration test was performed to confirm the long run relationships amongst the variables. Johansen (1988), Johansen and Joselius (1990) Cointegration test was adopted, the two proposed two different likelihood ratio tests: the trace test and maximum eigenvalue test, as shown in equations (1.5) and (1.6) respectively.

$$
\begin{aligned}
& J_{\text {trace }}=-T \sum_{i=r+1}^{n} \ln \left(1-\hat{\lambda}_{i}\right) \\
& J_{\max }=-T \ln \left(1-\hat{\lambda}_{r+1}\right)
\end{aligned}
$$


where: T is the sample size and $\hat{\lambda}_{i}$ is the $i^{\text {th }}$ largest canonical correlation. The trace test tests the null hypothesis of " $\mathbf{r}$ " cointegrating vectors against the alternative hypothesis of " $\mathbf{n}$ " cointegrating vectors. The maximum eigenvalue test, on the other hand, tests the null hypothesis of " $r$ " cointegrating vectors against the alternative hypothesis of $\mathbf{r}+\mathbf{1}$ cointegrating vectors.

\subsection{Results and Discussions.}

\subsection{Descriptive Statistics.}

Table 1 presents the descriptive statistics for the data collected. Mean average Cost of Credit was $M=88842.00$ $(S D=35476.94)$, this means that the average loans disbursed during the period of review had an average cost of kshs. 88,842.00 Million Charged over the period. Central Bank Rate, Non performing loans, Provisions in anticipation of loan losses and Treasury Bills had a mean of $M=12.57765(S D=3.707730) ; M=171556.1$ ( $S D$ $=87523.47) ; M=137850.5(S D=32506.62)$; and $M=249731.3(S D=164627.2)$ respectively, an indication that during the period of review, the Banking sector had an average of $12.575 \% \mathrm{CBR}$, Loans amounting to Kshs.171,556.1 Million were non performing, total provisions was Kshs.137,850.5 Million and had invested in kshs. 249,731.3 Million in treasury bills.

Table 1: Descriptive statistics - financial market frictions, flight to quality and Cost of Credit.

\begin{tabular}{lccccc}
\hline & CC & CBR & NPL & PALL & TBLL \\
\hline Mean & 88842.00 & 12.57765 & 171556.1 & 137850.5 & 249731.3 \\
Median & 80958.80 & 11.50000 & 160800.0 & 134900.0 & 188468.9 \\
Maximum & 147300.0 & 18.75000 & 347700.0 & 216700.0 & 610220.7 \\
Minimum & 24740.22 & 8.500000 & 56500.00 & 55600.00 & 39161.20 \\
Std. Dev. & 35476.94 & 3.707730 & 87523.47 & 32506.62 & 164627.2 \\
Skewness & 0.051221 & 0.438742 & 0.553438 & 0.090422 & 0.779435 \\
Kurtosis & 1.751861 & 1.526030 & 2.244132 & 4.655888 & 2.401986 \\
Jarque-Bera & 8.625894 & 16.18411 & 9.880808 & 15.26068 & 15.33234 \\
Probability & 0.013394 & 0.000306 & 0.007152 & 0.000485 & 0.000468 \\
Sum & 11727144 & 1660.250 & 22645400 & 18196267 & 32964535 \\
Sum Sq. Dev. & $1.65 \mathrm{E}+11$ & 1800.892 & $1.00 \mathrm{E}+12$ & $1.38 \mathrm{E}+11$ & $3.55 \mathrm{E}+12$ \\
Observations & 132 & 132 & 132 & 132 & 132 \\
\hline Key: CC= Cos & & $\mathrm{CB}$ & $\mathrm{Cen}$ &
\end{tabular}

Key: $\mathrm{CC}=$ Cost of Credit, $\mathrm{CBR}=$ Central bank Rate, $\mathrm{NPL}=$ Non Performing Loans,

$\mathrm{PALL}=$ Provisions in anticipation of Loan Losses, $\mathrm{TBLL}=$ Treasury Bills.

Source: Authors computations (2020)

\subsection{Diagnostic Tests.}

\subsubsection{Normality Test.}

Normality test was then conducted using Jarque-Bera statistics and the results are presented in Figure 2.0. The results shows that the $\mathrm{P}$ - value for the Jarque-Bera statistics is more than $5 \%$ (i.e $0.677570>p=0.05$ ), an indication that the data used were normally distributed.

Figure 2.0: Normality test for Market frictions, flight to quality and Cost of Credit data.

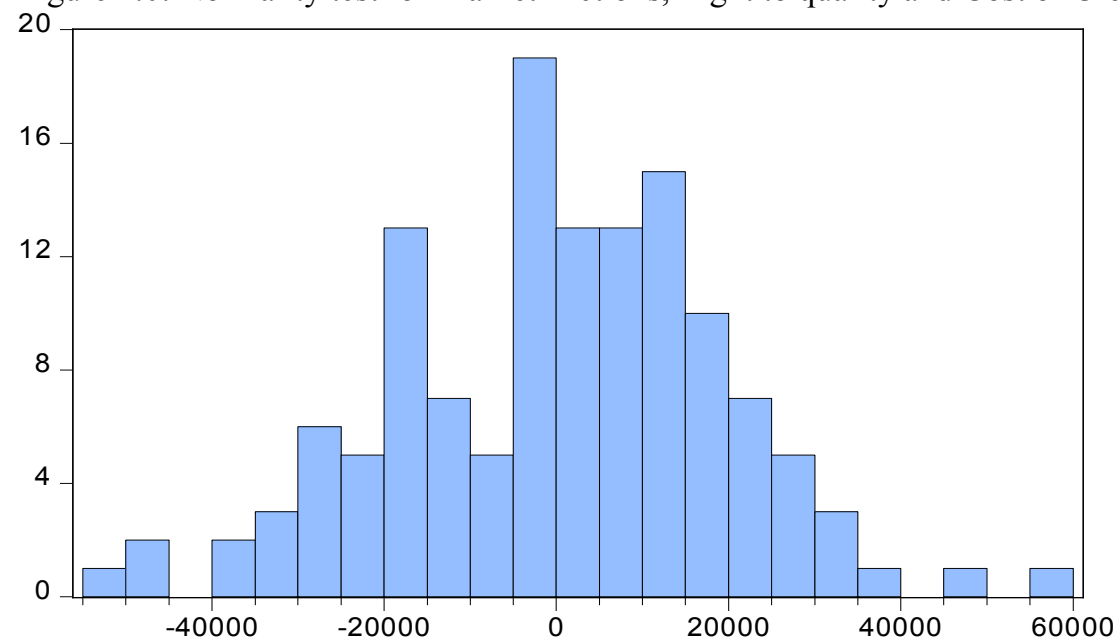

\begin{tabular}{lr} 
Series: Residuals \\
Sample 1 132 \\
Observations & \multicolumn{2}{l}{} \\
Or & \\
Mean & $-2.13 e-11$ \\
Median & 1605.643 \\
Maximum & 57570.67 \\
Minimum & -50605.31 \\
Std. Dev. & 19490.58 \\
Skewness & -0.176477 \\
Kurtosis & 3.130256 \\
& \\
Jarque-Bera & 0.778485 \\
Probability & 0.677570
\end{tabular}

Source: Author's computations (2020) 


\subsection{2: Test for Heteroskedasticity.}

The study further tested for the Breusch-Pagan-Godfrey Heteroskedasticity effect, with the null hypothesis that the error term was not heteroskedastic. Since the estimated P-value(s) corresponding to the observed R-squared was more than $5 \%(0.1127>0.05)$, the null hypothesis that the error term was not heteroskedastic was confirmed as seen in Table 2 .

F-statistic

Obs*R-squared

Scaled explained SS

$\begin{array}{ll}1.906804 & \text { Prob. F(4,127) } \\ 7.478371 & \text { Prob. Chi-Square(4) } \\ 7.373412 & \text { Prob. Chi-Square(4) }\end{array}$

0.1133

0.1127

0.1174

Table 2: Breusch-Pagan-Godfrey Heteroskedasticity Test for Cost of Credit and the Explanatory Variables

Source: Author's computations (2020)

3.3: Correlation Analysis.

Table 3: Correlation matrix of Cost of Credit, flight to quality and financial market frictions.

\begin{tabular}{c|rrrrr}
\hline \hline $\begin{array}{c}\text { Correlation } \\
\text { Probability }\end{array}$ & \multicolumn{1}{c}{ CC } & CBR & NPL & PALL & TBLL \\
\hline CC & 1.000000 & & & & \\
CBR & 0.805565 & 1.000000 & & & \\
& 0.0000 & & & & \\
NPL & 0.180101 & 0.210076 & 1.000000 & & \\
& 0.0388 & 0.0156 & & & \\
PALL & -0.296420 & -0.321434 & 0.105641 & 1.000000 & \\
& 0.0006 & 0.0002 & 0.2280 & & \\
TBLL & -0.687075 & -0.691151 & 0.176250 & 0.589743 & 1.000000 \\
& 0.0000 & 0.0000 & 0.0432 & 0.0000 & \\
\hline \hline
\end{tabular}

Key: $\mathrm{CC}=$ Cost of Credit, $\mathrm{CBR}=$ Central bank Rate, $\mathrm{NPL}=$ Non Performing Loans,

PALL $=$ Provisions in anticipation of Loan Losses, TBLL $=$ Treasury Bills.

Source: Author's computations (2020)

\subsection{Unit Root test.}

For stationarity of data to be achieved, the overall behavior of the data set should remain constant (Gujarat \& Porter, 2009). Stationarity of the time series data is important in ensuring that an accurate forecasting of events is realised. Time series data was therefore, first subjected to stationarity test. Augmented Dickey-Fuller test (ADF) and Philips perron test (PP) was used to test for the stationarity. As a rule of thumb, the null hypothesis assumes the presence of unit root, and the p-value obtained should be less than the significance level (e.g. 0.05) while the absolute value of the test statistic should also be less than the critical value for the rejection of the null hypothesis. Referring to the above rule of thumb, the data sets for CC, CBR, NPL, PALL and TBLL in table(s) 4 and 5 have unit root. The ADF $p$-values obtained for each data set was greater than $5 \% \quad(\mathrm{p}=0.05$ $<.5545, .1201, .3655, .9327, .9428)$, this compares well with the $\mathrm{p}$-values for PP ( $\mathrm{p}=0.05$ $<.5126, .2535, .3659, .0809, .9472)$ which are also clearly greater than $5 \%$. Similarly, the absolute values of the test statistics for each of the variables for both the ADF and PP are less than the corresponding absolute values of the test statistics at $5 \%$ level of significance. The study thus concludes that the series are non stationary at levels.

Table 4: Unit Root Test of the variables in level

\begin{tabular}{lllrrrl}
\hline & \multicolumn{7}{l}{ Augmented Dickey-Fuller test statistics } & & \\
\cline { 2 - 6 } Variable & At levels & p-value & $1 \%$ & $5 \%$ & $10 \%$ & Observation \\
\hline CC & -1.452559 & 0.5545 & -3.481217 & $-2.883753^{*}$ & -2.578694 & Unit Root exists \\
CBR & -2.490339 & 0.1201 & -3.480818 & $-2.883579^{*}$ & -2.578601 & Unit Root exists \\
NPL & -1.828236 & 0.3655 & -3.480818 & $-2.883579^{*}$ & -2.578601 & Unit Root exists \\
PALL & -0.212380 & 0.9327 & -3.483312 & $-2.884665^{*}$ & -2.579180 & Unit Root exists \\
TBLL & -0.130156 & 0.9428 & -3.480818 & $-2.883579^{*}$ & -2.578601 & Unit Root exists \\
\hline
\end{tabular}

Key: $\mathrm{CC}=$ Cost of Credit, $\mathrm{CBR}=$ Central bank Rate,

$\mathrm{NPL}=$ Non Performing Loans, $\mathrm{PALL}=$ Provisions in anticipation of

Loan Losses, TBLL $=$ Treasury Bills.

Source: Author's computations (2020) 
Table 5: Unit Root Test of the variables in level

\begin{tabular}{|c|c|c|c|c|c|c|}
\hline \multirow[b]{2}{*}{ Variable } & \multicolumn{5}{|c|}{ Philips - Perron Unit Root Test Statistics } & \multirow[b]{2}{*}{ Observation } \\
\hline & At levels & p-value & $1 \%$ & $5 \%$ & $10 \%$ & \\
\hline $\mathrm{CC}$ & -1.535630 & 0.5126 & -3.480818 & $-2.883579 *$ & -2.578601 & Unit Root exists \\
\hline CBR & -2.079143 & 0.2535 & -3.480818 & $-2.883579 *$ & -2.578601 & Unit Root exists \\
\hline NPL & -1.827297 & 0.3659 & -3.480818 & $-2.883579 *$ & -2.578601 & Unit Root exists \\
\hline PALL & -2.676218 & 0.0809 & -3.480818 & $-2.883579 *$ & -2.578601 & Unit Root exists \\
\hline TBLL & -0.091013 & 0.9472 & -3.480818 & $-2.883579 *$ & -2.578601 & Unit Root exists \\
\hline
\end{tabular}

Key: $\mathrm{CC}=$ Cost of Credit, $\mathrm{CBR}=$ Central bank Rate,

$\mathrm{NPL}=$ Non Performing Loans, $\mathrm{PALL}=$ Provisions in anticipation of

Loan Losses, TBLL= Treasury Bills.

Source: Author's computations (2020)

Table 6 and 7 shows the unit root test results for the series at first difference. From Tables 6 and 7 we can deduce that unit root does not exist in each of the series at first difference since the p-values for both the ADF and PP are less than $5 \%$ level of significance $(p=0.05<0.0000)$. The deduction is further supported by the absolute value of the test statistics for each of the variables which are more than the corresponding absolute value of the test statistics at 5\% level of significance. The study thus concludes that the series are stationary at first difference.

Table 6 : Unit Root Test of the variables after 1st Difference

\begin{tabular}{lllcccl}
\hline & \multicolumn{7}{l}{ Augmented Dickey-Fuller test statistics } & & \\
\cline { 2 - 6 } Variable & At levels & p-value & $1 \%$ & $5 \%$ & $10 \%$ & Observation \\
\hline D(CC) & -15.48620 & 0.0000 & -3.481217 & $-2.883753^{*}$ & -2.578694 & No Unit Root \\
D(CBR) & -13.93340 & 0.0000 & -3.481217 & $-2.883753^{*}$ & -2.578694 & No Unit Root \\
D(NPL) & -11.46304 & 0.0000 & -3.481217 & $-2.883753^{*}$ & -2.578694 & No Unit Root \\
D(PALL) & -8.858641 & 0.0000 & -3.483312 & $-2.884665^{*}$ & -2.579180 & No Unit Root \\
D(TBLL) & -11.18445 & 0.0000 & -3.481217 & $-2.883753^{*}$ & -2.578694 & No Unit Root \\
\hline
\end{tabular}

Key: $\mathrm{CC}=$ Cost of Credit, $\mathrm{CBR}=$ Central bank Rate, NPL $=$ Non Performing Loans,

$\mathrm{PALL}=$ Provisions in anticipation of Loan Losses, TBLL $=$ Treasury Bills.

Source: Author's computations (2020)

Table 7 : Unit Root Test of the variables after 1st Difference

\begin{tabular}{llccccl}
\hline & \multicolumn{7}{l}{ Philips - Perron Unit Root Test Statistics } & & \\
\cline { 2 - 6 } Variable & At levels & p-value & $1 \%$ & $5 \%$ & $10 \%$ & Observation \\
\hline D(CC) & -22.36075 & 0.0000 & -3.481217 & $-2.883753^{*}$ & -2.578694 & No Unit Root \\
D(CBR) & -21.08197 & 0.0000 & -3.481217 & $-2.883753^{*}$ & -2.578694 & No Unit Root \\
D(NPL) & -11.51830 & 0.0000 & -3.481217 & $-2.883753^{*}$ & -2.578694 & No Unit Root \\
D(PALL) & -11.62789 & 0.0000 & -3.481217 & $-2.883753^{*}$ & -2.578694 & No Unit Root \\
D(TBLL) & -11.18351 & 0.0000 & -3.481217 & $-2.883753^{*}$ & -2.578694 & No Unit Root \\
\hline
\end{tabular}

Key: $\mathrm{CC}=$ Cost of Credit, $\mathrm{CBR}=$ Central bank Rate,

$\mathrm{NPL}=$ Non Performing Loans, PALL $=$ Provisions in anticipation of

Loan Losses, TBLL $=$ Treasury Bills.

Source: Author's computations (2020)

\subsection{Vector Auto Regression (VAR) Lag Order Selection Criteria}

Table 8 shows VAR lag order selection criteria for Cost of Credit and the explanatory variables. Final prediction error (FPE), LR and Akaike information criterion (AIC) test statistic suggests lag 7 as the optimal lag. Schwarz information criterion (SC) and the Hannan-Quinn information criterion (HQ) suggest lag 1 as the optimal lag. Liew (2004) suggest that most economic sample data can seldom be considered large in size, AIC and FPE are therefore, recommended for the estimation of their autoregressive lag length, and since the observations in this study were relatively large, the Akaike information criterion (AIC) which suggested lag 7 at $93.85311^{*}$ was chosen for the autoregressive lag length for cost of credit. 
Table 8: VAR Lag Order Selection Criteria for Cost of Credit and the explanatory variables

\begin{tabular}{ccccccc}
\hline \hline Lag & LogL & LR & FPE & AIC & SC & HQ \\
\hline \hline 0 & -6369.859 & NA & $3.10 \mathrm{e}+38$ & 102.8203 & 102.9340 & 102.8665 \\
1 & -5808.828 & 1067.770 & $5.46 \mathrm{e}+34$ & 94.17464 & $94.85697^{*}$ & $94.45182^{*}$ \\
2 & -5793.660 & 27.64374 & $6.41 \mathrm{e}+34$ & 94.33323 & 95.58416 & 94.84139 \\
3 & -5779.106 & 25.35338 & $7.63 \mathrm{e}+34$ & 94.50170 & 96.32124 & 95.24084 \\
4 & -5748.536 & 50.78473 & $7.04 \mathrm{e}+34$ & 94.41187 & 96.80001 & 95.38199 \\
5 & -5717.485 & 49.08131 & $6.48 \mathrm{e}+34$ & 94.31427 & 97.27102 & 95.51537 \\
6 & -5682.350 & 52.70246 & $5.63 \mathrm{e}+34$ & 94.15080 & 97.67615 & 95.58288 \\
7 & -5638.893 & $61.68065^{*}$ & $4.31 \mathrm{e}+34^{*}$ & $93.85311^{*}$ & 97.94707 & 95.51617 \\
8 & -5621.060 & 23.87256 & $5.06 \mathrm{e}+34$ & 93.96872 & 98.63128 & 95.86276 \\
\hline \hline
\end{tabular}

* indicates lag order selected by the criterion

LR: sequential modified LR test statistic (each test at 5\% level)

FPE: Final prediction error

AIC: Akaike information criterion

SC: Schwarz information criterion

HQ: Hannan-Quinn information criterion

Source: Author's computations (2020)

\subsection{Cointegration Test}

Data was then subjected to Cointegration test, Johansen (1988) and Johansen and Joselius (1990) two different likelihood ratio tests were adopted. Since the variables were stationary at first difference as shown in tables 6 and 7 , cointegration test was therefore, necessary to establish a long run relationship. Results obtained from the Trace statistics and Maximum Eigenvalue Statistics as captured in Table 9 and Table 10 respectively, indicated that there is one (1) cointegrating equation or one error term $>$ At most $1, p=0.1740=17.4 \%$ and $p=0.2474=24.74 \%$ Statistics respectively at $5 \%$ level of significance, meaning all the variables are cointegrating. The null hypothesis that there is no Cointegrating equation is thus rejected. The results therefore, suggest that in the long run, the variables move together or have a long run association.

Table 9: Unrestricted Cointegration Rank Test (Trace) for Cost of Credit and the explanatory variables.

\begin{tabular}{ccccc}
\hline \hline $\begin{array}{c}\text { Hypothesized } \\
\text { No. of CE(s) }\end{array}$ & Eigenvalue & $\begin{array}{c}\text { Trace } \\
\text { Statistic }\end{array}$ & $\begin{array}{c}0.05 \\
\text { Critical Value }\end{array}$ & Prob.** $^{* *}$ \\
\hline \hline None & 0.290745 & 70.83750 & 69.81889 & 0.0414 \\
At most 1 & 0.118985 & 28.23857 & 47.85613 & 0.8033 \\
At most 2 & 0.063688 & 12.53023 & 29.79707 & 0.9118 \\
At most 3 & 0.033547 & 4.370280 & 15.49471 & 0.8715 \\
At most 4 & 0.001121 & 0.139075 & 3.841466 & 0.7092 \\
\hline \hline
\end{tabular}

Trace test indicates 1 cointegrating eqn(s) at the 0.05 level

* denotes rejection of the hypothesis at the 0.05 level

**MacKinnon-Haug-Michelis (1999) p-values

Source: Author's computations (2020) 
Table 10: Unrestricted Cointegration Rank Test (Maximum Eigenvalue) for Cost of Credit and the explanatory variables

\begin{tabular}{ccccc}
\hline \hline $\begin{array}{c}\text { Hypothesized } \\
\text { No. of CE(s) }\end{array}$ & Eigenvalue & $\begin{array}{c}\text { Max-Eigen } \\
\text { Statistic }\end{array}$ & $\begin{array}{c}0.05 \\
\text { Critical Value }\end{array}$ & Prob.** \\
\hline \hline None * & 0.290745 & 42.59893 & 33.87687 & 0.0036 \\
At most 1 & 0.118985 & 15.70835 & 27.58434 & 0.6904 \\
At most 2 & 0.063688 & 8.159947 & 21.13162 & 0.8936 \\
At most 3 & 0.033547 & 4.231205 & 14.26460 & 0.8342 \\
At most 4 & 0.001121 & 0.139075 & 3.841466 & 0.7092 \\
\hline \hline
\end{tabular}

Max-eigenvalue test indicates 1 cointegrating eqn(s) at the 0.05 level

* denotes rejection of the hypothesis at the 0.05 level

**MacKinnon-Haug-Michelis (1999) p-values

Source: Author's computations (2020)

Table 11 shows normalized cointegrating coefficients. From the table, while it can be concluded that Central Bank Rate and Treasury bills, on average, had a positive effect on cost of credit in the long run, Ceteris Paribus, Non-performing loans and Provision in anticipation for loan losses, on average, had a negative effect on cost of credit, ceteris paribus. The coefficients are statistically significant at $5 \%$ level. Since the coefficients are just OLS estimates, they have to be interpreted as ceteris paribus effects, and the signs reversed in the long run (Green, (2003); Gujarat and Porter, (2009); Wooldridge, (2009). The null hypothesis that there is no Cointegrating equation is thus rejected. This means that there is a cointegrating relationship in the model.

Table 11: Normalized cointegrating coefficients (standard error in parentheses) for cost of credit

\begin{tabular}{ccccc}
\hline \hline 1 Cointegrating Equation(s): & Log likelihood & -5637.077 & \\
\hline \hline CC & CBR & NPL & PALL & TBLL \\
1.000000 & -15334.03 & 0.082959 & -5.066735 & -0.082624 \\
& $(1966.24)$ & $(0.04605)$ & $(2.37272)$ & $(0.67689)$ \\
Adjustment coefficients (standard error in parentheses) & & \\
D(CC) & -0.153042 & & \\
& $(0.07447)$ & & \\
D(CBR) & $3.24 \mathrm{E}-05$ & & \\
& $(6.7 \mathrm{E}-06)$ & & \\
D(NPL) & -0.098528 & & \\
D(PALL) & $(0.17342)$ & & \\
D(TBLL) & -0.131603 & & \\
& $(0.07076)$ & & \\
\end{tabular}

Source: Author's computations (2020)

\subsection{Vector Error Correction Model.}

\subsubsection{Vector Error Correction Model for Cost of credit and its explanatory variables}

The vector error correction estimates (Appendix 1) were estimated based on the existence of the cointegrating equations. From the Appendix 1, the long run model explains the error correction term that signifies the long run relationship among the variables. As may be concluded from the estimates, the model posits that Central Bank rate, provisions in anticipation of loan losses, treasury bills and nonperforming loans are important determinants of cost of credit in the long run (t-statistics $2<-7.779867,2<2.80890$ and $2<-3.44197$ respectively), the null hypothesis that there is no long run relationship among the variables is rejected, Results in Appendix 1 shows that one unit change in Central Bank rate and treasury bills is associated with 15,334.03 units and 0.192070 units respectively, increase in cost of credit on average ceteris paribus in the long run. Both the Central Bank rate and Treasury bills were directly related to cost of credit. While on the other hand, one unit change in provisions in anticipation of loan losses and nonperforming loans is associated with 0.582190 units and 0.082959 units respectively, decrease in cost of credit on average ceteris paribus in the long run. Both the provisions in anticipation of loan losses and nonperforming loans were inversely related to cost of credit. The null hypothesis 
that there is no long run relationship among the variables is rejected.

$$
E C T_{t-1}=\left[\begin{array}{l}
1.00 C C_{t-1}-15334.03 C B R_{t-1}+0.082959 N P L_{t-1}+0.582190 P A L L_{t-1} \\
-0.192070 \text { TBLL }_{t-1} 56530.39
\end{array}\right]
$$

From the Appendix 1, the previous periods deviation from long run equilibrium is corrected in the current period at an adjustment speed of $15.3 \%$ ( CointEq1 $=-0.153042)$. Table 12 shows a make system approach, the results shows that Nonperforming loans, provisions in anticipation of loan losses and treasury bills are not important determinants of cost of credit in the short run, (t-statistics $2>0.798599 ; 2>0.988691$ and $2>-0.305125$ respectively), and were statistically insignificant at $5 \%$ level in the short run ( $\mathrm{p}=0.05<0.4267 ; \mathrm{p}=0.05<0.3256$; and $p=0.05<0.7610$ respectively), the null hypothesis that there is no short run relationship among the variables is accepted. Central Bank rate, however, returned as an important determinant of cost of credit (t-statistics $2<-$ $3.585777)$ and was statistically significant at $5 \%$ level $(\mathrm{p}=0.05>0.0006)$, and it had an expected negative sign $(\phi$ $=-3953.296$ ), which is a good sign, an indication that there is a short run relationship between Central Bank rate and Cost of Credit (Green, (2003); Gujarat and Porter, (2009); Wooldridge, (2009). The null hypothesis that there is no short run relationship between Central Bank rate and cost of credit is therefore, rejected. A Wald test statistic (table's 19a, b, c, and d) is further performed to confirm if indeed there is no short run relationship among the explanatory variables; Nonperforming loans, provisions in anticipation of loan losses, treasury bills and cost of credit. It was also used to confirm the short run causality between Central Bank rate and cost of credit.

$\Delta C C_{t}=-2657.863-0.145295 \Delta C C_{t-1}-3953.296 \Delta C B R_{t-1}+0.099037 \Delta P A L L_{t-1}+$

$$
0.039657 \triangle N P L_{t-1}-0.017641 \Delta T B L L_{t-1}-0.153042 E C T_{t-1}
$$

Table 12 shows the VECM that was estimated based on the existence of the cointegrating equations. The dependent variable was Cost of Credit (CC) while the independent variables were Central Bank Rate (CBR), Non Performing Loans (NPLs), Provisions in anticipation for Loan Losses (PALL) and Treasury Bills (TBLL). The error correction term indicated the expected sign and was significant at 5\% level (C (1) $=-0.153042, p=.0 .0429<$ 0.05 ), this means that the speed of adjustment towards long run equilibrium is negative and statistically significant. This implies that there is a long run causality running from Central Bank Rate (CBR) to cost of credit, in other words, Central Bank Rate has influence on cost of credit, this observation corroborates with Demetriades and Luintel (2001) who asserted that the use of interest rate ceilings, distorts the economy and inhibits financial deepening by depressing real rates of interest, consequently, MFIs levies other charges in a bid to recover their costs, in essence these additional charges increases cost of credit. Mohane et al, (2002) further supports this argument by stating that ceilings produces a series of adverse effects, they argue that since MFIs are not allowed to charge full cost recovery interest rates, they then drift up their operating costs thereby increasing their cost of credit. Table 18 also shows that there is a long run causality running from Non Performing Loans (NPLs) to cost of credit, this observation corroborates with Brown, Jappelli, and Pagano, (2009) whose estimates in their study showed that information sharing is associated with improved availability and lower cost of credit, Gaitho, (2013) observed that $\mathrm{CRB}$ reduces borrowing costs and loan delinquencies to a moderate extent.

These observations however, contradicts Khandare and Alshebami, (2015); Miller, (2013) argument that for MFIs to remain sustained and active in the market, it is mandatory for them to cover their costs; cost of borrowing, cost of operation, inflation cost, cost of default loans and other costs of delinquencies must be levied on the borrower and expenses incurred when carrying out their activities not forgetting to add their profit margin. There was also a long run causality running from Provisions in anticipation for Loan Losses to cost of credit, this corroborates Hela, Senda, Younes \& Collins (2016), they concluded that IFRS 9 adoption represents a key determinant of information asymmetry reduction, they argue this contributes significantly to decrease in cost of credit for post IFRS 9 period. This however, contradicts Chen et al, (2013), who indicated that IFRS adoption led to higher interest rates, greater likelihood of demand for collateral and shorter maturities, Gehrig and Stenbacka, (2007) who also contradicts this narrative stated that issues to do with lower credit ratings pay higher interest rates embodying larger risk premiums than higher rated issuers. Lastly, Table 18 shows that there exists a long run causality running from Treasury Bills to Cost of Credit; this observation corroborates Gubareva and Borges (2013) who noted that flight-to-quality events can be observed while correlation between safe and risky assets performance holds and, in some cases with increasing prices of risky assets, Jones, (2012) offered a further opinion arguing that flight to quality a cross financial markets have a strong negative interaction in sovereign debt markets, the structure of collaterals offered by individual micro enterprises led higher cost of credit. Their argument however, contradicts Gatev and Strahan (2006) who studied Banks' balance sheets and found out that when the spread between treasury bills and high grade commercial paper increases, Banks tend to experience inflows of deposits and decreased cost of funding. 
Table 12. Vector Error Correction Model and the System Equation for Cost of Credit Dependent Variable: D(CC)

Method: Least Squares (Gauss-Newton / Marquardt steps)

Sample (adjusted): 9132

Included observations: 124 after adjustments

$\mathrm{D}(\mathrm{CC})=\mathrm{C}(1) *(\mathrm{CC}(-1)-15334.0261931 * \mathrm{CBR}(-1)+0.0829594070514$

*NPL(-1) + 0.582189784479*PALL(-1) - 0.192069862133*TBLL(-1) +

$56530.3926015)+\mathrm{C}(2) * \mathrm{D}(\mathrm{CC}(-1))+\mathrm{C}(3) * \mathrm{D}(\mathrm{CC}(-2))+\mathrm{C}(4) * \mathrm{D}(\mathrm{CC}(-3))$

$+\mathrm{C}(5) * \mathrm{D}(\mathrm{CC}(-4))+\mathrm{C}(6) * \mathrm{D}(\mathrm{CC}(-5))+\mathrm{C}(7) * \mathrm{D}(\mathrm{CC}(-6))+\mathrm{C}(8) * \mathrm{D}(\mathrm{CC}(-7))$

$+\mathrm{C}(9) * \mathrm{D}(\mathrm{CBR}(-1))+\mathrm{C}(10) * \mathrm{D}(\mathrm{CBR}(-2))+\mathrm{C}(11) * \mathrm{D}(\mathrm{CBR}(-3))+\mathrm{C}(12)$

$* \mathrm{D}(\mathrm{CBR}(-4))+\mathrm{C}(13) * \mathrm{D}(\mathrm{CBR}(-5))+\mathrm{C}(14) * \mathrm{D}(\mathrm{CBR}(-6))+\mathrm{C}(15) * \mathrm{D}(\mathrm{CBR}($

-7)) + C(16)*D(NPL(-1)) + C(17)*D(NPL(-2)) + C(18)*D(NPL(-3)) +

$\mathrm{C}(19) * \mathrm{D}(\mathrm{NPL}(-4))+\mathrm{C}(20) * \mathrm{D}(\mathrm{NPL}(-5))+\mathrm{C}(21) * \mathrm{D}(\mathrm{NPL}(-6))+\mathrm{C}(22)$

$* \mathrm{D}(\mathrm{NPL}(-7))+\mathrm{C}(23) * \mathrm{D}(\mathrm{PALL}(-1))+\mathrm{C}(24) * \mathrm{D}(\mathrm{PALL}(-2))+\mathrm{C}(25) * \mathrm{D}(\mathrm{PALL}($

$-3))+\mathrm{C}(26) * \mathrm{D}(\mathrm{PALL}(-4))+\mathrm{C}(27) * \mathrm{D}(\mathrm{PALL}(-5))+\mathrm{C}(28) * \mathrm{D}(\mathrm{PALL}(-6))+$ $\mathrm{C}(29) * \mathrm{D}(\mathrm{PALL}(-7))+\mathrm{C}(30) * \mathrm{D}(\mathrm{TBLL}(-1))+\mathrm{C}(31) * \mathrm{D}(\mathrm{TBLL}(-2))+\mathrm{C}(32)$

$* \mathrm{D}(\mathrm{TBLL}(-3))+\mathrm{C}(33) * \mathrm{D}(\mathrm{TBLL}(-4))+\mathrm{C}(34) * \mathrm{D}(\mathrm{TBLL}(-5))+\mathrm{C}(35)$

$* \mathrm{D}(\mathrm{TBLL}(-6))+\mathrm{C}(36) * \mathrm{D}(\mathrm{TBLL}(-7))+\mathrm{C}(37)$

\begin{tabular}{|c|c|c|c|c|}
\hline & Coefficient & Std. Error & t-Statistic & Prob. \\
\hline $\mathrm{C}(1)$ & -0.153042 & 0.074472 & -2.055024 & 0.0429 \\
\hline $\mathrm{C}(2)$ & -0.280753 & 0.116530 & -2.409275 & 0.0181 \\
\hline $\mathrm{C}(3)$ & -0.230195 & 0.118100 & -1.949152 & 0.0545 \\
\hline $\mathrm{C}(4)$ & -0.241145 & 0.127314 & -1.894096 & 0.0615 \\
\hline $\mathrm{C}(5)$ & -0.047669 & 0.127073 & -0.375133 & 0.7085 \\
\hline $\mathrm{C}(6)$ & 0.087582 & 0.117147 & 0.747624 & 0.4567 \\
\hline $\mathrm{C}(7)$ & -0.145295 & 0.107680 & -1.349321 & 0.1807 \\
\hline $\mathrm{C}(8)$ & 0.150619 & 0.104026 & 1.447890 & 0.1512 \\
\hline $\mathrm{C}(9)$ & -1501.327 & 1246.263 & -1.204663 & 0.2316 \\
\hline$C(10)$ & -1651.559 & 1361.153 & -1.213352 & 0.2283 \\
\hline $\mathrm{C}(11)$ & -2948.099 & 1225.617 & -2.405400 & 0.0183 \\
\hline$C(12)$ & -1658.147 & 1216.470 & -1.363081 & 0.1764 \\
\hline $\mathrm{C}(13)$ & -2097.526 & 1099.167 & -1.908286 & 0.0597 \\
\hline$C(14)$ & -3953.296 & 1102.494 & -3.585777 & 0.0006 \\
\hline$C(15)$ & -360.4434 & 1103.425 & -0.326659 & 0.7447 \\
\hline$C(16)$ & -0.058215 & 0.046583 & -1.249688 & 0.2148 \\
\hline $\mathrm{C}(17)$ & -0.036327 & 0.046481 & -0.781555 & 0.4366 \\
\hline$C(18)$ & 0.011731 & 0.047319 & 0.247923 & 0.8048 \\
\hline$C(19)$ & -0.000613 & 0.048260 & -0.012697 & 0.9899 \\
\hline $\mathrm{C}(20)$ & -0.036601 & 0.046271 & -0.791015 & 0.4311 \\
\hline $\mathrm{C}(21)$ & 0.039657 & 0.049658 & 0.798599 & 0.4267 \\
\hline $\mathrm{C}(22)$ & -0.009090 & 0.051927 & -0.175061 & 0.8614 \\
\hline $\mathrm{C}(23)$ & 0.019035 & 0.110820 & 0.171765 & 0.8640 \\
\hline $\mathrm{C}(24)$ & -0.087110 & 0.102760 & -0.847702 & 0.3989 \\
\hline$C(25)$ & -0.111448 & 0.087554 & -1.272906 & 0.2064 \\
\hline$C(26)$ & -0.010655 & 0.089800 & -0.118655 & 0.9058 \\
\hline $\mathrm{C}(27)$ & -0.084158 & 0.091313 & -0.921643 & 0.3593 \\
\hline $\mathrm{C}(28)$ & 0.099037 & 0.100170 & 0.988691 & 0.3256 \\
\hline $\mathrm{C}(29)$ & -0.132993 & 0.107190 & -1.240716 & 0.2180 \\
\hline $\mathrm{C}(30)$ & 0.027159 & 0.058470 & 0.464491 & 0.6435 \\
\hline$C(31)$ & 0.038888 & 0.059600 & 0.652484 & 0.5158 \\
\hline$C(32)$ & 0.012957 & 0.058380 & 0.221936 & 0.8249 \\
\hline $\mathrm{C}(33)$ & 0.075946 & 0.058847 & 1.290553 & 0.2003 \\
\hline$C(34)$ & -0.002819 & 0.058709 & -0.048019 & 0.9618 \\
\hline$C(35)$ & -0.017641 & 0.057817 & -0.305125 & 0.7610 \\
\hline$C(36)$ & 0.003123 & 0.058532 & 0.053357 & 0.9576 \\
\hline $\mathrm{C}(37)$ & -2657.863 & 1522.141 & -1.746135 & 0.0843 \\
\hline
\end{tabular}




\begin{tabular}{lrlr}
\hline R-squared & 0.439463 & Mean dependent var & -759.6753 \\
Adjusted R-squared & 0.207517 & S.D. dependent var & 14245.71 \\
S.E. of regression & 12681.75 & Akaike info criterion & 21.97612 \\
Sum squared resid & $1.40 \mathrm{E}+10$ & Schwarz criterion & 22.81765 \\
Log likelihood & -1325.519 & Hannan-Quinn criter. & 22.31797 \\
F-statistic & 1.894676 & Durbin-Watson stat & 1.995054 \\
Prob(F-statistic) & 0.008307 & & \\
\hline \hline
\end{tabular}

Source: Author's computations (2020)

\subsection{Short run Causalities}

3.8.1. Short run casualties for cost of credit and its explanatory variables.

The study further employed Wald statistics to test whether or not the estimated coefficients in the VECM were significantly different from zero (i, e.) $\mathrm{C}(9)=\mathrm{C}(10)=\mathrm{C}(11)=\mathrm{C}(12)=\mathrm{C}(13)=\mathrm{C}(14)=\mathrm{C}(15)=0 ; \mathrm{C}(16)=$

$\mathrm{C}(17)=\mathrm{C}(18)=\mathrm{C}(19)=\mathrm{C}(20)=\mathrm{C}(21)=\mathrm{C}(22)=0 ; \mathrm{C}(23)=\mathrm{C}(24)=\mathrm{C}(25)=\mathrm{C}(26)=\mathrm{C}(27)=\mathrm{C}(28)=\mathrm{C}(29)=0 ;$ and $\mathrm{C}(30)$ $=\mathrm{C}(31)=\mathrm{C}(32)=\mathrm{C}(33)=\mathrm{C}(34)=\mathrm{C}(35)=\mathrm{C}(36)=0$. The Chi-square probability corresponding to the null hypothesis on Central Bank rate to cost of credit as presented in Table $13 \mathrm{a}$ is less than $5 \%(.0163<\mathrm{p}=0.05)$. Thus, the null hypothesis of $\mathrm{C}(9)=\mathrm{C}(10)=\mathrm{C}(11)=\mathrm{C}(12)=\mathrm{C}(13)=\mathrm{C}(14)=\mathrm{C}(15)=0$ is rejected, implying that there is short run causality running from Central Bank rate to cost of credit and is significantly different from zero. The Chi-square probability corresponding to the null hypothesis on other variables as presented in Table $13 \mathrm{a}$-d were more than $5 \%$ $(.8417 ; \quad .5603 ; \quad .9188>\mathrm{p}=0.05)$. Thus, the null hypothesis of $\mathrm{C}(16)=\mathrm{C}(17)=\mathrm{C}(18)=\mathrm{C}(19)=\mathrm{C}(20)=\mathrm{C}(21)=\mathrm{C}(22)=0 ; \mathrm{C}(23)=\mathrm{C}(24)=\mathrm{C}(25)=\mathrm{C}(26)=\mathrm{C}(27)=\mathrm{C}(28)=\mathrm{C}(29)=0 ; \quad$ and $\mathrm{C}(30)=\mathrm{C}(31)=\mathrm{C}(32)=\mathrm{C}(33)=\mathrm{C}(34)=\mathrm{C}(35)=\mathrm{C}(36)=0$ is accepted, implying that there is no short run causality running from Nonperforming loans to cost of credit as shown in Table 13b. Table 13c shows a similar observation from Provision in anticipation of loan losses to cost of credit. And lastly, Table 13d, indicates that there is no short run causality running from Treasury Bills to cost of credit. This is interdem with Kashyap, Stein, and Wilcox, (1993) who stated that, in the short run, the relation among the variables would be unstable and may fail to support the expectation hypothesis due to variable term premiums which are not under the control of the monetary authorities - especially in recent times when there are frictions after in the financial markets.

Table 13a: Wald Test for Central Bank Rate Coefficients on cost of credit

Wald Test:

Equation: Untitled

\begin{tabular}{lccc}
\hline \hline Test Statistic & Value & df & Probability \\
\hline \hline F-statistic & 2.454014 & $(7,87)$ & 0.0241 \\
Chi-square & 17.17810 & 7 & 0.0163 \\
\hline \hline
\end{tabular}

Null Hypothesis: $\mathrm{C}(9)=\mathrm{C}(10)=\mathrm{C}(11)=\mathrm{C}(12)=\mathrm{C}(13)=\mathrm{C}(14)=\mathrm{C}($

$15)=0$

Null Hypothesis Summary:

\begin{tabular}{lcc}
\hline \hline Normalized Restriction $(=0)$ & Value & Std. Err. \\
\hline \hline $\mathrm{C}(9)$ & -1501.327 & 1246.263 \\
$\mathrm{C}(10)$ & -1651.559 & 1361.153 \\
$\mathrm{C}(11)$ & -2948.099 & 1225.617 \\
$\mathrm{C}(12)$ & -1658.147 & 1216.470 \\
$\mathrm{C}(13)$ & -2097.526 & 1099.167 \\
$\mathrm{C}(14)$ & -3953.296 & 1102.494 \\
$\mathrm{C}(15)$ & -360.4434 & 1103.425 \\
\hline \hline
\end{tabular}

Restrictions are linear in coefficients.

Source: Author's computations (2020) 
Table 13b: Wald Test for Non Performing Loans Coefficients on cost of credit

Wald Test:

Equation: Untitled

\begin{tabular}{lccc}
\hline \hline Test Statistic & Value & df & Probability \\
\hline \hline F-statistic & 0.491261 & $(7,87)$ & 0.8386 \\
Chi-square & 3.438827 & 7 & 0.8417 \\
\hline \hline
\end{tabular}

Null Hypothesis: $\mathrm{C}(16)=\mathrm{C}(17)=\mathrm{C}(18)=\mathrm{C}(19)=\mathrm{C}(20)=\mathrm{C}(21)=$

$$
\mathrm{C}(22)=0
$$

Null Hypothesis Summary:

\begin{tabular}{lcc}
\hline \hline Normalized Restriction $(=0)$ & Value & Std. Err. \\
\hline \hline $\mathrm{C}(16)$ & -0.058215 & 0.046583 \\
$\mathrm{C}(17)$ & -0.036327 & 0.046481 \\
$\mathrm{C}(18)$ & 0.011731 & 0.047319 \\
$\mathrm{C}(19)$ & -0.000613 & 0.048260 \\
$\mathrm{C}(20)$ & -0.036601 & 0.046271 \\
$\mathrm{C}(21)$ & 0.039657 & 0.049658 \\
$\mathrm{C}(22)$ & -0.009090 & 0.051927 \\
\hline \hline
\end{tabular}

Restrictions are linear in coefficients.

Source: Author's computations (2020)

Table 13c: Wald Test for Provision in anticipation of loan losses Coefficients on cost of credit Wald Test:

Equation: Untitled

\begin{tabular}{lccc}
\hline \hline Test Statistic & Value & df & Probability \\
\hline \hline F-statistic & 0.832166 & $(7,87)$ & 0.5635 \\
Chi-square & 5.825164 & 7 & 0.5603 \\
\hline \hline
\end{tabular}

Null Hypothesis: $\mathrm{C}(23)=\mathrm{C}(24)=\mathrm{C}(25)=\mathrm{C}(26)=\mathrm{C}(27)=\mathrm{C}(28)=$ $\mathrm{C}(29)=0$

Null Hypothesis Summary:

\begin{tabular}{lcc}
\hline \hline Normalized Restriction $(=0)$ & Value & Std. Err. \\
\hline \hline $\mathrm{C}(23)$ & 0.019035 & 0.110820 \\
$\mathrm{C}(24)$ & -0.087110 & 0.102760 \\
$\mathrm{C}(25)$ & -0.111448 & 0.087554 \\
$\mathrm{C}(26)$ & -0.010655 & 0.089800 \\
$\mathrm{C}(27)$ & -0.084158 & 0.091313 \\
$\mathrm{C}(28)$ & 0.099037 & 0.100170 \\
$\mathrm{C}(29)$ & -0.132993 & 0.107190
\end{tabular}

Restrictions are linear in coefficients.

Source: Author's computations (2020) 
Table 13d: Wald Test for Treasury bills Coefficients on cost of credit

Wald Test:

Equation: Untitled

\begin{tabular}{|c|c|c|c|}
\hline Test Statistic & Value & $\mathrm{df}$ & Probability \\
\hline $\begin{array}{l}\text { F-statistic } \\
\text { Chi-square }\end{array}$ & $\begin{array}{l}0.372409 \\
2.606864\end{array}$ & $\begin{array}{c}(7,87) \\
7\end{array}$ & $\begin{array}{l}0.9161 \\
0.9188\end{array}$ \\
\hline \multicolumn{4}{|c|}{$\begin{array}{l}\text { Null Hypothesis: } C(30)=C(31)=C(32)=C(33)=C(34)=C(35)= \\
\qquad C(36)=0 \\
\text { Null Hypothesis Summary: }\end{array}$} \\
\hline Normalized Restriction $(=0)$ & & Value & Std. Err. \\
\hline $\begin{array}{l}C(30) \\
C(31) \\
C(32) \\
C(33) \\
C(34) \\
C(35) \\
C(36)\end{array}$ & & $\begin{array}{r}0.027159 \\
0.038888 \\
0.012957 \\
0.075946 \\
-0.002819 \\
-0.017641 \\
0.003123\end{array}$ & $\begin{array}{l}0.058470 \\
0.059600 \\
0.058380 \\
0.058847 \\
0.058709 \\
0.057817 \\
0.058532\end{array}$ \\
\hline
\end{tabular}

Restrictions are linear in coefficients.

Source: Author's computations (2020)

\subsection{Post Analysis diagnostic Tests}

Table 14 shows Breusch-Godfrey Serial Correlation LM Test for cost of credit that was conducted on the data post the analysis to assess any possibility of serial correlation. The test yielded an observed $R 2$ of $0.100120 \mathrm{P}$ $=.9512>0.05$, suggesting lack of serial correlation.

Table 14: Breusch-Godfrey Serial Correlation LM post analysis Test for cost of credit

\begin{tabular}{lllr}
\hline \hline F-statistic & 0.034343 & Prob. F(2,85) & 0.9663 \\
Obs*R-squared & 0.100120 & Prob. Chi-Square(2) & 0.9512 \\
\hline \hline
\end{tabular}

Source: Author's computations (2020)

The study further tested for the Autoregressive Conditional Heteroskedasticity (ARCH) effect on cost of credit, with the null hypothesis that there was no ARCH effect. Since the estimated P-value corresponding to the observed R squared was .8241>0.05, the null hypothesis that there was no ARCH effect was confirmed as seen in Table 15.

Table 15: Heteroskedasticity post analysis Test: ARCH for cost of credit

\begin{tabular}{lllr}
\hline \hline F-statistic & 0.048618 & Prob. F(1,121) & 0.8259 \\
Obs*R-squared & 0.049402 & Prob. Chi-Square(1) & 0.8241 \\
\hline \hline
\end{tabular}

Source: Author's computations (2020)

\subsection{Summary and Conclusion.}

The study investigated the long-run and short- run relationships among financial market frictions, flight to quality and cost of credit using Johansen's methodology of multivariate cointegration analysis and Vector Error Correction Model. The objective was to determine the effect of Central Bank rate on cost of credit in Kenya. Correlation results shows that Central Bank rate was positively associated with the cost of credit and was significant at $5 \%$ level $(\mathrm{r}=.805565 ; .0000>\mathrm{p}=.05)$; vector error correction estimates indicated that Central Bank rate is an important determinant of cost of credit in the long run ( $t$-statistics $2<-7.79867)$. Vector error correction term coefficient shows that one unit change in Central Bank rate was associated with 15334.03 units increase in cost of credit on average ceteris paribus in the long run. The null hypothesis that there is no long run relationship between Central Bank rate and cost of credit is therefore, rejected and the alternative accepted. Wald statistics results shows that there is a short run causality running from Central Bank rate to cost of credit and was significantly different from zero at $5 \%$ level $(\mathrm{C}(9)=\mathrm{C}(10)=\mathrm{C}(11)=\mathrm{C}(12)=\mathrm{C}(13)=\mathrm{C}(14)=\mathrm{C}(15)=0 ;(.0163<\mathrm{p}=0.05)$. The null hypothesis 
that there is no short run relationship between Central Bank rate and cost of credit is therefore, rejected and the alternative accepted. This finding invalidates this study's null hypothesis that Central Bank rate does not affect cost of credit in Kenya. This study concludes that market frictions i.e ceilings that are set too low are problematic especially in cases where they do not cover fees and commissions. World over, even if such ceilings are intended to reduce usury and exorbitant lending by MFIs who charge very high interest rates, they are very difficult to enforce. Moreover, lending practices without prudent regard for repayment capacity of micro enterprises, deceptive terms, and unlawful collection techniques causes more damage to microenterprises than do high interest rates. This is in agreement with Onyango and Odondo, (2018); Acclassato, (2006); Mohane et al, (2002) who elaborated that when interest rate ceilings are implemented, MFIs may be forced to impose additional charges which are not part of interest rates to cover administrative costs, this not only reduces transparency about the borrowers true cost of borrowing but also camouflages the actual interest rates charged by MFIs even if on surface, the cost may appear to be reducing like in the case of interest rate ceilings as shown in this study.

The second objective was to establish the effect of provisions in anticipation of loan losses on cost of credit in Kenya. From the research findings, correlation results revealed that provisions in anticipation of loan losses was negatively associated with cost of credit and was significant at $5 \%$ level $(r=-.296420 ; .0006>p=.05)$; vector error correction estimates denoted that provisions in anticipation of loan losses is an important determinant of cost of credit in the long run ( $\mathrm{t}$-statistics $2<2.80890)$. Vector error correction term coefficient suggested that one unit change in provisions in anticipation of loan losses was associated with 0.582190 units decrease in cost of credit on average ceteris paribus in the long run. The null hypothesis that there is no long run relationship between provisions in anticipation of loan losses and cost of credit is therefore, rejected and the alternative accepted. Wald statistics results shows that there is no short run causality running from provisions in anticipation of loan losses to cost of credit and was not significantly different from zero at $5 \%$ level $C(23)=C(24)=C(25)=C(26)=C(27)=C(28)=$ $\mathrm{C}(29)=0 ;(.5603>\mathrm{p}=0.05)$. The null hypothesis that there is no short run relationship between provisions in anticipation of loan losses and cost of credit is therefore, accepted and the alternative rejected. This study concludes that provisions in anticipation of loan losses affects cost of credit in the long run, provisions mitigates the MFIs against losses occasioned by loan default, costs that arise due to loan loss and default such as; costs associated with monitoring loans in arrears, post disbursement visits, costs of hiring external debt recovery experts, and other costs of delinquencies are greatly reduced since IFRS 9 is forward looking and loans are properly appraised and provided for at all times, this consequently reduces cost of credit.

As depicted in the research findings, correlation results evidenced that non-performing loans was positively associated with cost of credit and was significant at $5 \%$ level $(.0388>\mathrm{p}=.05)$. The null hypothesis that there is no long run relationship between non-performing loans and cost of credit is therefore, rejected and the alternative accepted. Wald statistics results shows that there is no short run causality running from non-performing loans to cost of credit and was not significantly different from zero at $5 \%$ level $C(16)=C(17)=C(18)=C(19)=C(20)=C(21)=$ $\mathrm{C}(22)=0 ;(.0539>\mathrm{p}=0.05)$. The null hypothesis that there is no short run relationship between non-performing loans and Cost of Credit is therefore, accepted and the alternative rejected. The results of this study draw the conclusion that MFIs holding greater levels of NPLs are claimed for increasing profitability by equity investors in the long-run.

Investors perceive these MFIs as riskier than their counterparts or other assets, claiming greater returns on the equity holdings of these MFIs and hence inducing an increase in their cost of credit.

The last objective was to determine the long run relationship between flight to quality and cost of credit in Kenya. From the research findings, correlation results revealed that flight to quality was negatively associated with cost of credit and was significant at $5 \%$ level $(r=-.687075 ; .0000>p=.05)$; vector error correction estimates elucidated that flight to quality is not an important determinant of cost of credit in the long run (t-statistics $2>$ 3.44197). The null hypothesis that there is no long run relationship between flight to quality and cost of credit is therefore, rejected and the alternative accepted. Wald statistics results shows that there is no short run causality running from flight to quality to cost of credit and was not significantly different from zero at $5 \%$ level $\mathrm{C}(30)=\mathrm{C}(31)=\mathrm{C}(32)=\mathrm{C}(33)=\mathrm{C}(34)=\mathrm{C}(35)=\mathrm{C}(36)=0 ;(.9188>\mathrm{p}=0.05)$. The null hypothesis that there is no short run relationship between flight to quality and cost of credit is therefore, accepted and the alternative rejected. This study concludes that the increasing Treasury Bills take up by MFIs, is not a good sign to micro borrowers either, as it simply shows that there could be a flight to quality effect on Micro lending. This is the usury argument, most MFI's will tend to invest to a more profitable and risk free non funded income ventures like treasury bills. The findings in this is a confirmation of this argument, this however, is not a good news to borrowers as MFI's as tend to shrink lending in favour such investments, adverse selection and stringent measures are therefore employed to identify the qualified borrowers, those with unidentifiable credit worthiness and risk are denied access, with the reduced credit supply, the cost of delinquencies associated with lending also deceases with the decreasing credit supply. 


\subsection{Recommendation.}

In view of the findings, the explanatory variables for financial market frictions and flight to quality significantly affects cost of credit in the long run, based on the findings, this study recommends that pegging interest rates on Central Bank rate is good as it protects unsuspecting individuals from being exploited by the MFIs, however, it also comes with usury charges to cover their administrative and operating costs, as such the Government should incorporate MFIs opinions and views in a way that will allow them charge interests which are neither high or low but enough cover their costs to remain in business, MFIs are also advised to invest in non funded income to maximize their profits. It is also prudent for MFIs to invest in online and mobile lending in order to reduce administrative and operating costs.

\section{References}

Acclassato, H., D.,(2006). Microfinance institutions under interest rates ceilings. Orleans, France: University of Orleans.

Bernanke, B and C Lown (1991): "The credit crunch", Brookings Papers on Economic Activity, No 2, pp 205-39.

Bernanke, B and A Blinder (1988): "Credit, money and aggregate demand", American Economic Review 98, (May 1988), 435-439.

Brown, M., Jappelli, T., and Pagano, M., (2009), Information sharing and credit: Firm-level evidence from transition countries. University of Naples Federico, Italy; J. Finan. Intermediation 18 (2009) 151-172

Caballero, R., Krishnamurthy, A., 2008, Collective risk management in a flight to quality episode. Journal of Finance 63, 2195-2230.

Central Bank of Kenya -CBK. (2016). Bank Supervision Annual Report. Retrieved, April 17 from https://www.centralbank.go.ke/index.php/bank-supervision-reports.

Cyert, R. M., P. Kumar \& J. R. Williams (1993). Information, market imperfections and strategy, Strategic Management Journal, 27: 401-423.

Cohen, B and M Scatigna (2016): "Banks and capital requirements: channels of adjustment", Journal of Banking and Finance, vol 69, supp 1, pp S56-S69.

Chen, T., Chin, C. L., Wang, S., \& Yao, C. (2013). The Effect of Mandatory IFRS Adoption on Bank Loan Contracting. Disponível em: http://papers.ssrn.com/sol3/papers.cfm? abstract id=2159001.

DeFond, M., Hu, X., Hung, M., \& Li, S. (2011). The impact of IFRS adoption on foreign mutual fund ownership: the role of comparability. Journal of Accounting and Economics, 51(3), 240- 58.

Demetriades, P. O., and Luintel, K. (2001). "Financial Restraints in the South Korean Miracle." Journal of Development Economics 64 (2): 459-79.

Gaitho, N.W. (2013). The role of credit reference bureaus on credit access in Kenya. European Scientific Journal, $9(13), 1857-7881$.

Gambacorta, L and H S Shin (2016): "Why bank capital matters for monetary policy", BIS Working Papers, no 558, April.

Gatev, E., Strahan, P.E., (2006). Banks' advantage in hedging liquidity risk: theory and evidence from the commercial paper market. Journal of Finance 61, 867-892

Gehrig, T., \& Stenbacka, R. (2007). Information Sharing and Lending Market Competition with Switching Costs and Poaching. European Economic Review, 51, 77-99.

Gubareva, M., \& Borges, M., R., (2013)Typological Classification, Diagnostics, and Measurement of Flights-toQuality, Technical University of Lisbon, WP 15/2013/DE/UECE

Gujarat and Porter, (2009) Basic Econometrics, $5^{\text {th }}$ Edition.

Guler, B., and Ozlale, U.,( 2005). Is there a flight-to-quality due to inflation uncertainty?.

Green, W. H., (2003) Econometric Analysis, $5^{\text {th }}$ Edition.

Hela, Senda, Younes \& Collins (2016) the effect of IFRS mandatory adoption on the information asymmetry Hela Turki1 *, Senda Wali1 and Younes Boujelbene1; Turkiet al., Cogent Business \& Management (2016), 3: $1209100 \mathrm{http} / / / \mathrm{dx}$. doi.org/10.1080/23311975.2016.1209100

Jones, E. (2012), Eurobonds, Flight to Quality, and TARGET2 Imbalances. European Policy Analysis 4, 1-12.

Kashyap, Anil K., Jeremy C. Stein, \& David W. Wilcox, (1993). Monetary policy and credit conditions: Evidence from the composition of external finance. American Economic Review 83:1, 78-98 (March).

Khandare, D. M.,\&Alshebami, A. S., ( 2015), The Impact of Interest Rate Ceilings on Microfinance Industry, School of Commerce \& Management Science, SRTM University, India, International Journal of Social Work ISSN 2332-7278.

Kishan, R and T Opiela (2000): "Bank size, bank capital, and the bank lending channel", Journal of Money, Credit and Banking, vol 32, pp 121- 41.

Kishan, R and T Opiela (2006): "Bank capital and loan asymmetry in the transmission of monetary policy", Journal of Banking and Finance, vol 30, pp 249-85.

Kiyotaki \& R. Wright (1989) “On Money as a Medium of Exchange,” JPE 97, 927-54. 
Kothari, C. R. (2004).Research Methodology: Methods and Techniques, (Second Edition), New Age International Publishers.

Liew, V. K (2004). Which lag selection Criteria Should we employ? Economics Bulletin, 3(33), 1-9.

Maimbo, S. M., \& Gallegos, C. A. H.(2014). "Interest Rate Caps around the World" Still Popular, but a Blunt Instrument, Policy Research Working Paper 7070. World Bank Group.

Mahony J. T. \& Qian L. (2009). Market Frictions, Governance and Economic Rents: Taking Stock and Looking Ahead, University of Illinois at Urbana-Champaign, College of Business

Miller, H. (2013). Interest Rate Caps and Their Impact on Financial Inclusion. Economic and Private Sector, Professional Evidence and Applied Knowledge Services. February 2013.EPS-PEAKS.

Moosa, I.A. and R.H. Bhatti, 1997, "Are Asian markets integrated? Evidence for six countries vis-à-vis Japan”, International Economic Journal, 11, pp. 51-67.

Mohane, H., Gerhard C. \& William, G. (2002), The Effects of the Interest Rate Ceilings on the Micro Lending Market in South Africa. University of Pretoria.Department of Agricultural Economics, Extension and Rural Development. Working paper: 2002-02.

Onyango, B., O., \& Odondo, A., J., (2018), Logit Analysis of the Relationship between Interest Rate Ceiling and Micro Lending Market in Kenya, International Journal of Economics and Finance; Vol. 10, No. 8; 2018 ISSN 1916-971X E-ISSN 1916-9728 Published by Canadian Center of Science and Education

Saunders, M., Lewis, P. \&Thornhill, A. (2009).Research methods for business students, 5th ed., Harlow, Pearson Education.

Trejos \& R. Wright (1995) “Search, Bargaining, Money, and Prices," JPE 103, 118-41.

Wooldridge J. M., (2009) Introductory Econometrics, A modern approach, $4^{\text {th }}$ Edition.

\section{Appendices}

Appendix 1: Normalized Vector Error Correction Estimates for Cost of Credit

Vector Error Correction Estimates

Sample (adjusted): 8132

Included observations: 125 after adjustments

Standard errors in ( ) \& t-statistics in [ ]

\begin{tabular}{|c|c|c|c|c|c|}
\hline Cointegrating Eq: & CointEq1 & & & & \\
\hline $\mathrm{CC}(-1)$ & 1.000000 & & & & \\
\hline \multirow[t]{3}{*}{$\mathrm{CBR}(-1)$} & -15334.03 & & & & \\
\hline & (1966.24) & & & & \\
\hline & {$[-7.79867]$} & & & & \\
\hline \multirow[t]{3}{*}{ NPL(-1) } & 0.082959 & & & & \\
\hline & $(0.04605)$ & & & & \\
\hline & [ 1.80143$]$ & & & & \\
\hline \multirow[t]{3}{*}{ PALL(-1) } & 0.582190 & & & & \\
\hline & $(0.20727)$ & & & & \\
\hline & [2.80890] & & & & \\
\hline \multirow[t]{3}{*}{ TBLL(-1) } & -0.192070 & & & & \\
\hline & $(0.05580)$ & & & & \\
\hline & {$[-3.44197]$} & & & & \\
\hline $\mathrm{C}$ & 56530.39 & & & & \\
\hline Error Correction: & $\mathrm{D}(\mathrm{CC})$ & $\mathrm{D}(\mathrm{CBR})$ & $\mathrm{D}(\mathrm{NPL})$ & $\mathrm{D}(\mathrm{PALL})$ & $\mathrm{D}(\mathrm{TBLL})$ \\
\hline \multirow[t]{3}{*}{ CointEq1 } & -0.153042 & $3.24 \mathrm{E}-05$ & -0.098528 & -0.131603 & 0.020896 \\
\hline & $(0.07447)$ & $(6.7 \mathrm{E}-06)$ & $(0.17342)$ & $(0.07076)$ & $(0.13101)$ \\
\hline & {$[-2.05502]$} & [ 4.86179] & {$[-0.56814]$} & {$[-1.85994]$} & [0.15950] \\
\hline \multirow[t]{3}{*}{$\mathrm{D}(\mathrm{CC}(-1))$} & -0.280753 & $-1.81 \mathrm{E}-05$ & -0.093932 & 0.129235 & 0.088512 \\
\hline & $(0.11653)$ & $(1.0 \mathrm{E}-05)$ & $(0.27136)$ & $(0.11072)$ & $(0.20500)$ \\
\hline & {$[-2.40928]$} & {$[-1.73162]$} & {$[-0.34615]$} & [ 1.16726$]$ & [ 0.43177$]$ \\
\hline \multirow[t]{3}{*}{$\mathrm{D}(\mathrm{CC}(-2))$} & -0.230195 & $-3.08 \mathrm{E}-05$ & -0.200058 & 0.227909 & -0.179292 \\
\hline & $(0.11810)$ & $(1.1 \mathrm{E}-05)$ & $(0.27502)$ & $(0.11221)$ & $(0.20776)$ \\
\hline & {$[-1.94915]$} & [-2.90708] & {$[-0.72744]$} & [2.03112] & {$[-0.86298]$} \\
\hline \multirow[t]{2}{*}{$\mathrm{D}(\mathrm{CC}(-3))$} & -0.241145 & $-2.45 \mathrm{E}-05$ & -0.346744 & 0.088619 & -0.249349 \\
\hline & $(0.12731)$ & $(1.1 \mathrm{E}-05)$ & $(0.29647)$ & $(0.12096)$ & $(0.22397)$ \\
\hline
\end{tabular}




\begin{tabular}{|c|c|c|c|c|c|}
\hline & {$[-1.89410]$} & {$[-2.14620]$} & {$[-1.16956]$} & {$[0.73261]$} & [-1.11333] \\
\hline \multirow[t]{3}{*}{$\mathrm{D}(\mathrm{CC}(-4))$} & -0.047669 & $-1.90 \mathrm{E}-05$ & -0.117016 & 0.041023 & -0.022439 \\
\hline & $(0.12707)$ & $(1.1 \mathrm{E}-05)$ & $(0.29591)$ & $(0.12073)$ & $(0.22354)$ \\
\hline & {$[-0.37513]$} & {$[-1.66527]$} & {$[-0.39544]$} & {$[0.33978]$} & {$[-0.10038]$} \\
\hline \multirow[t]{3}{*}{$\mathrm{D}(\mathrm{CC}(-5))$} & 0.087582 & $-2.38 \mathrm{E}-05$ & -0.145775 & 0.164071 & 0.159961 \\
\hline & $(0.11715)$ & $(1.0 \mathrm{E}-05)$ & $(0.27280)$ & (0.11130) & $(0.20608)$ \\
\hline & {$[0.74762]$} & {$[-2.26289]$} & {$[-0.53437]$} & {$[1.47410]$} & {$[0.77620]$} \\
\hline \multirow[t]{3}{*}{$\mathrm{D}(\mathrm{CC}(-6))$} & -0.145295 & $-3.17 \mathrm{E}-05$ & 0.054581 & 0.266266 & -0.059517 \\
\hline & $(0.10768)$ & $(9.6 \mathrm{E}-06)$ & $(0.25075)$ & $(0.10231)$ & $(0.18943)$ \\
\hline & {$[-1.34932]$} & {$[-3.28785]$} & {$[0.21767]$} & [2.60260] & {$[-0.31419]$} \\
\hline \multirow[t]{3}{*}{$\mathrm{D}(\mathrm{CC}(-7))$} & 0.150619 & $-1.17 \mathrm{E}-05$ & -0.253100 & 0.094496 & 0.009472 \\
\hline & $(0.10403)$ & $(9.3 \mathrm{E}-06)$ & $(0.24224)$ & $(0.09884)$ & $(0.18300)$ \\
\hline & [ 1.44789$]$ & {$[-1.25463]$} & {$[-1.04481]$} & {$[0.95608]$} & {$[0.05176]$} \\
\hline \multirow[t]{3}{*}{$\mathrm{D}(\mathrm{CBR}(-1))$} & -1501.327 & 0.217002 & -122.6347 & -5303.275 & 5434.171 \\
\hline & $(1246.26)$ & $(0.11167)$ & $(2902.15)$ & (1184.09) & $(2192.40)$ \\
\hline & {$[-1.20466]$} & [ 1.94319$]$ & {$[-0.04226]$} & {$[-4.47879]$} & [2.47864] \\
\hline \multirow{3}{*}{$\mathrm{D}(\mathrm{CBR}(-2))$} & -1651.559 & 0.218703 & -1110.633 & -1581.121 & -1414.146 \\
\hline & $(1361.15)$ & $(0.12197)$ & $(3169.70)$ & (1293.25) & $(2394.51)$ \\
\hline & {$[-1.21335]$} & {$[1.79311]$} & {$[-0.35039]$} & {$[-1.22260]$} & {$[-0.59058]$} \\
\hline \multirow[t]{3}{*}{$\mathrm{D}(\mathrm{CBR}(-3))$} & -2948.099 & 0.249228 & 2368.010 & -2157.135 & -2750.759 \\
\hline & $(1225.62)$ & $(0.10982)$ & $(2854.08)$ & (1164.47) & $(2156.08)$ \\
\hline & {$[-2.40540]$} & [2.26936] & [ 0.82969$]$ & {$[-1.85246]$} & {$[-1.27582]$} \\
\hline \multirow[t]{3}{*}{$\mathrm{D}(\mathrm{CBR}(-4))$} & -1658.147 & 0.109505 & -5701.502 & -2222.762 & -519.6397 \\
\hline & $(1216.47)$ & $(0.10900)$ & $(2832.78)$ & $(1155.78)$ & $(2139.99)$ \\
\hline & {$[-1.36308]$} & {$[1.00459]$} & {$[-2.01269]$} & {$[-1.92317]$} & {$[-0.24282]$} \\
\hline \multirow[t]{3}{*}{$\mathrm{D}(\mathrm{CBR}(-5))$} & -2097.526 & 0.115615 & -1597.035 & -1914.518 & 3483.537 \\
\hline & (1099.17) & $(0.09849)$ & $(2559.61)$ & $(1044.33)$ & (1933.63) \\
\hline & {$[-1.90829]$} & [ 1.17384$]$ & {$[-0.62394]$} & {$[-1.83325]$} & [ 1.80155$]$ \\
\hline \multirow[t]{3}{*}{$\mathrm{D}(\mathrm{CBR}(-6))$} & -3953.296 & 0.193127 & -2096.981 & -1443.159 & -3109.548 \\
\hline & $(1102.49)$ & $(0.09879)$ & $(2567.36)$ & $(1047.49)$ & (1939.48) \\
\hline & {$[-3.58578]$} & [ 1.95492$]$ & {$[-0.81679]$} & {$[-1.37773]$} & {$[-1.60329]$} \\
\hline \multirow[t]{3}{*}{$\mathrm{D}(\mathrm{CBR}(-7))$} & -360.4434 & 0.172326 & -3481.927 & 230.0031 & -324.5545 \\
\hline & (1103.42) & $(0.09887)$ & $(2569.53)$ & $(1048.38)$ & (1941.12) \\
\hline & {$[-0.32666]$} & [ 1.74289$]$ & {$[-1.35508]$} & [ 0.21939$]$ & {$[-0.16720]$} \\
\hline \multirow[t]{3}{*}{ D(NPL(-1)) } & -0.058215 & $1.40 \mathrm{E}-06$ & -0.007966 & -0.015766 & 0.107286 \\
\hline & $(0.04658)$ & $(4.2 \mathrm{E}-06)$ & $(0.10848)$ & $(0.04426)$ & $(0.08195)$ \\
\hline & {$[-1.24969]$} & [ 0.33643$]$ & {$[-0.07344]$} & {$[-0.35621]$} & [ 1.30919] \\
\hline \multirow[t]{3}{*}{ D(NPL(-2)) } & -0.036327 & $-1.78 \mathrm{E}-07$ & -0.097382 & -0.031210 & -0.136368 \\
\hline & $(0.04648)$ & $(4.2 \mathrm{E}-06)$ & $(0.10824)$ & $(0.04416)$ & $(0.08177)$ \\
\hline & {$[-0.78156]$} & {$[-0.04286]$} & {$[-0.89970]$} & {$[-0.70672]$} & {$[-1.66775]$} \\
\hline \multirow[t]{3}{*}{$\mathrm{D}(\mathrm{NPL}(-3))$} & 0.011731 & $-6.89 \mathrm{E}-06$ & 0.007824 & 0.034301 & 0.390985 \\
\hline & $(0.04732)$ & $(4.2 \mathrm{E}-06)$ & $(0.11019)$ & $(0.04496)$ & $(0.08324)$ \\
\hline & [ 0.24792$]$ & {$[-1.62535]$} & [ 0.07101$]$ & {$[0.76296]$} & [ 4.69695] \\
\hline \multirow[t]{3}{*}{ D(NPL(-4)) } & -0.000613 & $-3.43 \mathrm{E}-06$ & -0.142725 & 0.008279 & -0.006012 \\
\hline & $(0.04826)$ & $(4.3 \mathrm{E}-06)$ & $(0.11238)$ & $(0.04585)$ & $(0.08490)$ \\
\hline & {$[-0.01270]$} & {$[-0.79284]$} & {$[-1.26998]$} & {$[0.18056]$} & {$[-0.07082]$} \\
\hline \multirow[t]{3}{*}{ D(NPL(-5)) } & -0.036601 & $1.61 \mathrm{E}-05$ & -0.016293 & 0.031083 & 0.066112 \\
\hline & $(0.04627)$ & $(4.1 \mathrm{E}-06)$ & $(0.10775)$ & $(0.04396)$ & $(0.08140)$ \\
\hline & {$[-0.79101]$} & [3.87178] & {$[-0.15121]$} & {$[0.70704]$} & [0.81220] \\
\hline \multirow[t]{3}{*}{ D(NPL(-6)) } & 0.039657 & $-1.05 \mathrm{E}-05$ & -0.128982 & 0.063940 & -0.052067 \\
\hline & $(0.04966)$ & $(4.4 \mathrm{E}-06)$ & $(0.11564)$ & $(0.04718)$ & $(0.08736)$ \\
\hline & {$[0.79860]$} & {$[-2.36887]$} & {$[-1.11540]$} & {$[1.35521]$} & {$[-0.59602]$} \\
\hline $\mathrm{D}(\mathrm{NPL}(-7))$ & -0.009090 & $-7.27 \mathrm{E}-06$ & 0.013720 & -0.029145 & 0.182320 \\
\hline & $(0.05193)$ & $(4.7 \mathrm{E}-06)$ & $(0.12092)$ & $(0.04934)$ & $(0.09135)$ \\
\hline & {$[-0.17506]$} & {$[-1.56345]$} & {$[0.11347]$} & {$[-0.59073]$} & [ 1.99587$]$ \\
\hline $\mathrm{D}(\operatorname{PALL}(-1))$ & 0.019035 & $-2.03 \mathrm{E}-05$ & 0.080122 & -0.175507 & 0.019256 \\
\hline & $(0.11082)$ & $(9.9 \mathrm{E}-06)$ & $(0.25807)$ & $(0.10529)$ & $(0.19495)$ \\
\hline & {$[0.17176]$} & {$[-2.04644]$} & [ 0.31047$]$ & {$[-1.66687]$} & [ 0.09877$]$ \\
\hline $\mathrm{D}(\operatorname{PALL}(-2))$ & -0.087110 & $-1.16 \mathrm{E}-05$ & 0.370261 & 0.075891 & 0.510238 \\
\hline
\end{tabular}




\begin{tabular}{|c|c|c|c|c|c|}
\hline & $(0.10276)$ & $(9.2 \mathrm{E}-06)$ & $(0.23930)$ & $(0.09763)$ & $(0.18077)$ \\
\hline & {$[-0.84770]$} & {$[-1.25847]$} & [ 1.54729$]$ & {$[0.77730]$} & [ 2.82253] \\
\hline \multirow[t]{3}{*}{$\mathrm{D}(\operatorname{PALL}(-3))$} & -0.111448 & $2.47 \mathrm{E}-05$ & -0.173747 & 0.022606 & -0.162781 \\
\hline & $(0.08755)$ & $(7.8 \mathrm{E}-06)$ & $(0.20389)$ & $(0.08319)$ & $(0.15402)$ \\
\hline & {$[-1.27291]$} & [ 3.14896] & {$[-0.85217]$} & {$[0.27176]$} & {$[-1.05686]$} \\
\hline \multirow[t]{3}{*}{ D(PALL(-4)) } & -0.010655 & $-1.19 \mathrm{E}-05$ & -0.399370 & 0.173576 & -0.241736 \\
\hline & $(0.08980)$ & $(8.0 \mathrm{E}-06)$ & $(0.20912)$ & $(0.08532)$ & $(0.15797)$ \\
\hline & {$[-0.11866]$} & {$[-1.47727]$} & {$[-1.90980]$} & [ 2.03441] & {$[-1.53023]$} \\
\hline \multirow[t]{3}{*}{ D(PALL $(-5))$} & -0.084158 & $-8.39 \mathrm{E}-06$ & -0.267549 & -0.419821 & -0.028146 \\
\hline & $(0.09131)$ & $(8.2 \mathrm{E}-06)$ & $(0.21264)$ & $(0.08676)$ & $(0.16064)$ \\
\hline & {$[-0.92164]$} & {$[-1.02579]$} & {$[-1.25823]$} & {$[-4.83899]$} & {$[-0.17522]$} \\
\hline \multirow[t]{3}{*}{ D(PALL(-6)) } & 0.099037 & $-1.86 \mathrm{E}-05$ & -0.156894 & -0.298023 & -0.180694 \\
\hline & $(0.10017)$ & $(9.0 \mathrm{E}-06)$ & $(0.23326)$ & $(0.09517)$ & $(0.17622)$ \\
\hline & [ 0.98869$]$ & {$[-2.07463]$} & {$[-0.67260]$} & {$[-3.13140]$} & {$[-1.02541]$} \\
\hline \multirow[t]{3}{*}{ D(PALL(-7)) } & -0.132993 & $-7.66 \mathrm{E}-06$ & 0.398384 & 0.020549 & 0.390728 \\
\hline & $(0.10719)$ & $(9.6 \mathrm{E}-06)$ & $(0.24961)$ & $(0.10184)$ & $(0.18857)$ \\
\hline & {$[-1.24072]$} & {$[-0.79778]$} & [ 1.59601$]$ & [ 0.20178$]$ & [2.07209] \\
\hline \multirow[t]{3}{*}{$\mathrm{D}(\mathrm{TBLL}(-1))$} & 0.027159 & $1.17 \mathrm{E}-05$ & 0.056412 & -0.083478 & 0.104467 \\
\hline & $(0.05847)$ & $(5.2 \mathrm{E}-06)$ & $(0.13616)$ & $(0.05555)$ & $(0.10286)$ \\
\hline & [ 0.46449$]$ & [ 2.23475$]$ & [0.41431] & {$[-1.50267]$} & [ 1.01563$]$ \\
\hline \multirow[t]{3}{*}{$\mathrm{D}(\mathrm{TBLL}(-2))$} & 0.038888 & $5.29 \mathrm{E}-06$ & 0.036369 & -0.060849 & -0.079536 \\
\hline & $(0.05960)$ & $(5.3 \mathrm{E}-06)$ & $(0.13879)$ & $(0.05663)$ & $(0.10485)$ \\
\hline & [ 0.65248$]$ & [ 0.99068$]$ & [ 0.26205$]$ & {$[-1.07457]$} & {$[-0.75860]$} \\
\hline \multirow[t]{3}{*}{$\mathrm{D}(\mathrm{TBLL}(-3))$} & 0.012957 & $-1.34 \mathrm{E}-06$ & 0.290790 & 0.038588 & 0.111095 \\
\hline & $(0.05838)$ & $(5.2 \mathrm{E}-06)$ & $(0.13595)$ & $(0.05547)$ & $(0.10270)$ \\
\hline & [ 0.22194$]$ & {$[-0.25708]$} & [2.13898] & [ 0.69569$]$ & [ 1.08174$]$ \\
\hline \multirow[t]{3}{*}{$\mathrm{D}(\mathrm{TBLL}(-4))$} & 0.075946 & $1.38 \mathrm{E}-05$ & -0.096263 & -0.125363 & -0.066740 \\
\hline & $(0.05885)$ & $(5.3 \mathrm{E}-06)$ & $(0.13704)$ & $(0.05591)$ & $(0.10352)$ \\
\hline & [ 1.29055$]$ & [ 2.62629] & {$[-0.70246]$} & {$[-2.24217]$} & {$[-0.64469]$} \\
\hline \multirow[t]{3}{*}{$\mathrm{D}(\mathrm{TBLL}(-5))$} & -0.002819 & $-9.14 \mathrm{E}-10$ & 0.018941 & -0.127860 & -0.094336 \\
\hline & $(0.05871)$ & $(5.3 \mathrm{E}-06)$ & $(0.13672)$ & $(0.05578)$ & $(0.10328)$ \\
\hline & {$[-0.04802]$} & {$[-0.00017]$} & [0.13854] & {$[-2.29220]$} & {$[-0.91340]$} \\
\hline \multirow[t]{3}{*}{$\mathrm{D}(\mathrm{TBLL}(-6))$} & -0.017641 & $1.28 \mathrm{E}-05$ & 0.198515 & 0.097448 & -0.062893 \\
\hline & $(0.05782)$ & $(5.2 \mathrm{E}-06)$ & $(0.13464)$ & $(0.05493)$ & $(0.10171)$ \\
\hline & {$[-0.30513]$} & [2.46661] & [ 1.47444$]$ & [ 1.77396$]$ & {$[-0.61836]$} \\
\hline \multirow[t]{3}{*}{ D(TBLL(-7)) } & 0.003123 & $5.81 \mathrm{E}-08$ & 0.036370 & 0.040597 & -0.011887 \\
\hline & $(0.05853)$ & $(5.2 \mathrm{E}-06)$ & $(0.13630)$ & $(0.05561)$ & $(0.10297)$ \\
\hline & {$[0.05336]$} & [ 0.01108$]$ & [ 0.26684$]$ & {$[0.73000]$} & {$[-0.11545]$} \\
\hline \multirow[t]{3}{*}{$\mathrm{C}$} & -2657.863 & -0.240128 & -4361.820 & 1977.931 & 4180.180 \\
\hline & $(1522.14)$ & $(0.13639)$ & $(3544.59)$ & $(1446.20)$ & $(2677.72)$ \\
\hline & {$[-1.74613]$} & {$[-1.76055]$} & {$[-1.23056]$} & [ 1.36767$]$ & [ 1.56110$]$ \\
\hline R-squared & 0.439463 & 0.604968 & 0.233444 & 0.620356 & 0.475963 \\
\hline Adj. R-squared & 0.207517 & 0.441507 & -0.083752 & 0.463261 & 0.259121 \\
\hline Sum sq. resids & $1.40 \mathrm{E}+10$ & 112.3459 & $7.59 \mathrm{E}+10$ & $1.26 \mathrm{E}+10$ & $4.33 \mathrm{E}+10$ \\
\hline S.E. equation & 12681.75 & 1.136368 & 29531.79 & 12049.06 & 22309.45 \\
\hline F-statistic & 1.894676 & 3.700985 & 0.735962 & 3.948939 & 2.194971 \\
\hline Log likelihood & -1325.519 & -169.8290 & -1430.337 & -1319.173 & -1395.560 \\
\hline Akaike AIC & 21.97612 & 3.335952 & 23.66672 & 21.87376 & 23.10581 \\
\hline Schwarz SC & 22.81765 & 4.177488 & 24.50826 & 22.71530 & 23.94734 \\
\hline Mean dependent & -759.6753 & -0.076613 & -392.7419 & 805.6452 & 3934.282 \\
\hline S.D. dependent & 14245.71 & 1.520583 & 28367.75 & 16446.44 & 25918.81 \\
\hline
\end{tabular}

Key:CC $=$ Cost of Credit, $\mathrm{CBR}=$ Central bank Rate, $\mathrm{NPL}=$ Non Performing Loans, $\mathrm{PALL}=$ Provisions in anticipation of Loan Losses, TBLL $=$ Treasury Bills.

Source: Author's computations (2020) 